\title{
Family knowledge on newborn care
}

\author{
Conhecimentos de familiares sobre os cuidados com recém-nascidos \\ Conocimientos de familiares acerca de la atención a recién nacidos
}

Ana Leticia Monteiro Gomes ${ }^{1}$, Cristiane Rodrigues da Rocha², Danielle de Mendonça Henrique ${ }^{3}$, Mirza Almeida Santos $^{2}$, Leila Rangel da Silva ${ }^{2}$

Objective: analyzing the knowledge that families acquired on newborn care, before and after their participation in a motherfather-infant welcoming group. Methods: a quantitative and descriptive study that took place in a municipal health center, with 27 participants. Data were collected by a questionnaire applied before and after the educational activity, and was analyzed by comparing the answers of the items. Results: care actions properly modified were: the use of baby powder, soap, tea, objects in the navel, sun bathing time, correct hygiene of male genitalia, attention to child's records and physiological eliminations. Conclusion: the families reported positive changes in newborn care through participation in health education activities, suggesting that the activity developed with caregivers can reduce risks to the health of newborn babies.

Descriptors: Infant, Newborn; Health Education; Nursing.

Objetivo: analisar os conhecimentos que os familiares adquiriram sobre os cuidados com o recém-nascido, antes e após sua participação no grupo de acolhimento mãe-pai-bebê. Métodos: estudo quantitativo e descritivo, cujo cenário foi um centro municipal de saúde, com 27 participantes. Os dados foram coletados por um questionário aplicado antes e após a atividade educativa e analisados comparando-se as respostas por itens. Resultados: os cuidados corretamente modificados foram: utilização de talco, sabonete, chá, objetos no umbigo, horário do banho de sol, correta higienização da genitália masculina, cuidados com a caderneta da criança e as eliminações fisiológicas. Conclusão: os familiares informaram mudanças positivas para os cuidados dos recém-nascidos mediante a participação das ações de educação em saúde, sugerindo que essa atividade desenvolvida com os cuidadores permite reduzir riscos à saúde de recém-nascidos.

Descritores: Recém-Nascido; Educação em Saúde; Enfermagem.

Objetivo: analizar los conocimientos que familiares adquirieron acerca de la atención al recién nacido antes y después de la participación de estos en el grupo de acogimiento madre-padre-hijo. Métodos: estudio cuantitativo y descriptivo, cuyo escenario fue un centro de salud municipal, con 27 participantes. Datos recogidos mediante cuestionario aplicado antes y después de la actividad educativa y analizados mediante comparación de las respuestas por ítems. Resultados: atención adecuadamente cambiada: uso de talco, jabón, té, objetos en el ombligo, tiempo para tomar el sol, correcta limpieza de los genitales masculinos, cuidado con el libro de niños y eliminaciones fisiológicas. Conclusión: los familiares informaron cambios positivos para atención a los recién nacidos a través de la participación en actividades de educación en salud, sugiriéndose que esta actividad desarrollada con los cuidadores puede reducir riesgos a la salud de recién nacidos.

Descriptores: Recién Nacido; Educación en Salud;Enfermería.

\footnotetext{
${ }^{1}$ Universidade Federal do Rio de Janeiro. Rio de Janeiro, RJ, Brazil.

${ }^{2}$ Universidade Federal do Estado do Rio de Janeiro. Rio de Janeiro, RJ, Brazil.

${ }^{3}$ Universidade do Estado do Rio de Janeiro. Rio de Janeiro, RJ, Brazil.

Corresponding author: Ana Leticia Monteiro Gomes

Rua Florianópolis, 811 apt 401. Praça Seca. CEP: 21321-050. Rio de Janeiro, RJ Brazil. E-mail: analeticiagomes88@gmail.com
} 


\section{Introduction}

The neonatal period is a time of great vulnerability, concentrated biological, environmental, social and cultural risks, so there is need for special care with timely actions, integrated and qualified social protection and health ${ }^{(1)}$. Among the care activities, educational practices are important strategies to decrease the exposure of the newborn to those risks that can expose them to illness, thus negatively reflecting in neonatal mortality and morbidity indices.

Health education is a key element in the activities carried out by primary care professionals. Educational practices are used as a trade tool between popular and scientific knowledge, in order to reconstruct meanings and attitudes ${ }^{(2)}$. It is noteworthy that educational activities are embedded in the work of health professionals, particularly for nurses, who are essential to the care provided ${ }^{(3)}$.

Educational actions permeate most of the nursing service in health institutions, as was observed in a study of 15 nurses of the Family Health Strategy unitin Crato (Ceará/Brazil). This study found that these health professionals value health education practices and incorporate them in their daily activities ${ }^{(4)}$.

However, few studies systematically address the educational models used in health education activities. Knowledge of these models is necessary so that these activities can be structured in order to achieve their goals ${ }^{(5)}$.

Currently, the emerging model of health education is the dialogic model, to have dialogue as its central element. The user is characterized as the subject knowledge bearer, which although being different from technical and scientific knowledge, is not discriminated as such by health professionals. It is believed that educational activities based on dialogic model facilitate the autonomy and empowerment of mothers/parents/family for home care of babies in order to achieve integral and humanized familycentered care ${ }^{(5-6)}$.

Therefore, the training of parents and family is fundamental so that they become autonomous and responsible for the care of their newborn in the family context, since health education can give parents the empowerment of knowledge to care for their baby ${ }^{(6)}$.

Thus, the object of this study is the influence of educational groups on maternal knowledge and/ or family about the care of the newborn, and was designed with the following objective: to analyze the knowledge that family members had on the care of the newborn before and after participation in hosting a group of mother-family-baby.

This article intends to produce content that can contribute to the development of strategies for educating on newborn care in health facilities, especially for the family, as well as the basis for assessing the service of relative health education offered to the population. In the scope of the research, other studies on the subject area can be supported by the results and referenced bibliographies.

\section{Method}

A quantitative, descriptive, cross-sectional non-experimental research. The scenario for data collection was the Municipal Health Center in the city of Rio de Janeiro. The unit is a mixed type, with care being performed by teams of a family health strategy unit and possessing outpatient specializations. The Municipal Health Center conducts daily care in pediatrics, in two types of assistance, in addition to being a reference for the care of children with asthma, and infant pneumonitis.

The study was composed by a convenience sample consisting of participants who sought the health service to monitor their child's healthcare during the period of January-March 2013. Thus, 
the study included 17 mothers, four fathers, three grandparents and three aunts, totaling 27 people, referred to in this study as family members.

The activities in the mother-infant-family host group were performed by a nurse once a week in an appropriate environment, lasting about 40 minutes per meeting. During the survey period, there were six meetings with the participation of researchers in six host groups with an average of 4.5 participants per group. The educational model used in the group was dialogical, and the family of the newborn had the opportunity to exchange experiences and clarify doubts regarding the newborn care. In addition, the nurse always addressed the following topics in the group: oral and personal hygiene, umbilical stump, cramping, sun bathing, breastfeeding, children's health record/booklet, physiological eliminations and warning signs of diseases/health aggravations.

The data collection phase took place during the period from January to March 2013. A questionnaire with closed questions was used ${ }^{(6)}$, adapted to the reality of the basic health unit. The instrument addressed questions about the child's health booklet, hygiene, umbilical stump, cramping, breastfeeding and warning signs of health problems. They also discussed some aspects of maternal health, such as: number of prenatal consultations and advice or health information developed at the hospital. The questionnaire consisted of 27 questions, with four answers through options of yes/no, 17 by choosing correct answers among alternatives and six options for characterization of respondents.

Data collection occurred in the large room service itself, being in a welcoming environment and preserving the privacy of the participants. The questionnaire was carried out in two stages: before and after the participation of the family in the host group. The responses in two stages (before and after) favored further knowledge and, consequently, if the formation was successful with respect to knowledge of the subject.

Data were processed with the help of EPIINFO $®$ software, version 3.5.2, public domain software directed to the healthcare area, and specifically for the part of epidemiology, created by the Centers for Disease Control and Prevention. Calculations used were absolute and relative frequencies for comparison of knowledge before and after the educational activity.

The study was approved by the Ethics Committee of the Municipal Health Secretariat of the city of Rio de Janeiro, under protocol number 162/12, and obtained the consent of research subjects by their signing the Clear and Informed Consent form.

\section{Results}

Regarding the degree of relationship of the family member with newborns, the majority (63.0\%) were mothers. Among the participants, $70.3 \%$ were single. Age of family ranged between 18 and 68 years, and $55.5 \%$ were in the range of $18-28$ years. With regards to schooling, 55.5\% reported having attended high school.

All mothers $(n=17)$ underwent prenatal care. Among them, $78.6 \%$ attended six or more visits, while $21.4 \%$ attended fewer than six. In relation to the guidelines received on newborn care, $75 \%$ of mothers were informed at the hospital.

The data before and after the group practice were processed and divided into eight categories: Hygiene care; Umbilical stump care; Cramping care; Sunbathing Care; Breastfeeding Care; Caring for the child's health records; Physiological Elimination Care; Caring for warning signs of diseases/health aggravations (Table 1). 
Table 1 - Results about knowledge on newborn care obtained before and after the group activity

\begin{tabular}{|c|c|c|}
\hline Categories & $\begin{array}{l}\text { Before* } \\
(\%)\end{array}$ & $\begin{array}{l}\text { After* } \\
(\%)\end{array}$ \\
\hline \multicolumn{3}{|l|}{ Hygiene care } \\
\hline Does not use baby powder & 74.1 & 89.3 \\
\hline Hygiene at every intestinal elimination & 96.4 & 96.4 \\
\hline $\begin{array}{l}\text { Oral hygiene with filtered water and gauze/ } \\
\text { clean cloth }\end{array}$ & 96.4 & 96.4 \\
\hline Correct hygiene of female genitals & 100 & 100.0 \\
\hline Correct hygiene of male genitals & 92.9 & 100.0 \\
\hline Careful not to rub the fontanelle at bath time & 92.9 & 96.4 \\
\hline \multicolumn{3}{|l|}{ Care with umbilical stump } \\
\hline Umbilical stump hygiene with $70 \%$ alcohol & 100.0 & 100.0 \\
\hline Necessity to placing objects in the navel & 10.7 & - \\
\hline \multicolumn{3}{|l|}{ Cramping care } \\
\hline Giving lemongrass tea to eliminate cramps & 7.1 & - \\
\hline \multicolumn{3}{|l|}{ Sunbath care } \\
\hline Sun bathing time 7:00 - 9:00 a.m. & 96.4 & 100.0 \\
\hline The sun helps the production of vitamin $\mathrm{D}$ & 78.6 & 96.4 \\
\hline It is normal if the baby is yellowish & 7.1 & 7.1 \\
\hline \multicolumn{3}{|l|}{ Breastfeeding Care } \\
\hline Baby crying because the milk is weak & - & - \\
\hline Need to give water to the baby $<6$ months old & 3.6 & 3.6 \\
\hline Positioning and correct latching & 96.4 & 96.4 \\
\hline \multicolumn{3}{|l|}{ Caring for the child's health records } \\
\hline Records need to be assessed monthly & 75.0 & 78.6 \\
\hline \multicolumn{3}{|l|}{ Care of physiological eliminations } \\
\hline Evacuation within seven days & 100.0 & 100.0 \\
\hline $\begin{array}{l}\text { Elimination of blood and transparent secretion } \\
\text { in female newborns is normal }\end{array}$ & 35.7 & 92.9 \\
\hline \multicolumn{3}{|l|}{ Caring for warning signs } \\
\hline $\begin{array}{l}\text { Taking the baby who has a warning sign to a } \\
\text { health service }\end{array}$ & 100.0 & 100.0 \\
\hline
\end{tabular}

\section{Discussion}

In Brazil, there is a decrease in the fertility rate of childbearing aged women, showing that the higher the level of income and education level, the lower the number of conceptions. On the other hand, for those with less education, the number of children reaches three, while for women with higher levels of schooling, the number of children is around one $\mathrm{e}^{(7)}$. This relationship resembled the present study, in which most of the respondents with children had little insertion in the school environment.

Mothers are the primary caregivers of newborns, however, there are different people involved in care, such as the child's parent due to women having greater participation in the formal and informal labor market. As indicated, the father's role in participation of child development has been expanding but mothers are characterized as the primary caregivers ${ }^{(8)}$.

Marital status does not interfere in child health care. However, as shown in the state of Rio de Janeiro, $54.1 \%$ of the population over 10 years of age is single ${ }^{(9)}$. However, in this study, there was a higher percentage of unmarried than the average of the state, stressing that marital status has no bearing on child care.

As recommended during the prenatal period, pregnant women should attend at least six appointments/visits. However, such consultation must be systematic, focusing on quality of care and service, that is, going beyond a simple number of consultations. Nevertheless, as disclosed, there is the aggravating factor that the quality of consultations sometimes does not meet the minimum standards of the necessary condition, which can be evidenced by the high incidence of congenital syphilis in our territory ${ }^{(10)}$. In order to observe a reduction of information during the consultation sessions, in some cases such deficiency in prenatal care still has a chance for intervention in the maternity ward, expanding the necessary information for comprehensive newborn care.

A multicenter epidemiological study in Brazil performed in a population of infants under one year of age, concluded that the promotion of breastfeeding among the population and the increasing prevalence might imply a reduction of hospitalizations ${ }^{(11)}$. Therefore, to assist in the reduction of hospital readmission rates, it is necessary to minimize the difficulties presented for breastfeeding mothers to 
provide handle/latch position and orientation.

In order to prevent diaper rash, completely drying the baby after bath without applying baby powder is recommended during diaper changing ${ }^{(12)}$. With this, there was a change in the concept for caregivers of what was important in newborn health, as observed in reducing use of baby powder on newborns before and after group intervention, thereby demonstrating the effectiveness of the information discussed during the study.

Oral hygiene of the newborn must be performed with filtered water and gauze/clean cloth. From the first days of life, the adoption of oral care should be encouraged and motivated by health team professionals, as these habitual healthy lifestyle practices will prevent the onset of oral diseases in infancy, reflecting on health promotion for life ${ }^{(13)}$.

In caring for the intimate hygiene of the newborn, it is not advised to use the soap directly on the skin and minimize using perfumes, thereby reducing allergic sensitization to topical agents. In the present study, there was the incorporation of knowledge even before the group discussion, probably because this subject is broad in daily life. Female genital hygiene should be done with damp cotton balls in warm water, in the anteroposterior direction with large longitudinal movements to prevent contamination of the urethral and vaginal canal, especially if there is presence of feces.

Neonates have six fontanelles, which are spaces between skull bones that are held by a flexible membrane that is stretched when the baby has any kind of symptom. It is recommended that the fontanelle should not be rubbed in the shower. In the present study, this knowledge was not absorbed by all participants, since there were doubts about such care regarding the hygiene of the newborn's head.

The umbilical vessels are functionally closed after the birth, but they are anatomically pervious for 10 to 20 days and may constitute a port of input for bacteria. The fall of the umbilical stump usually occurs between the first and second week of life, since its permanence beyond 30 days is associated with neutrophil function problems or a major bacterial contamination $^{(14)}$. Therefore, the navel of the newborn can easily be contaminated, causing infections that risk the child's life. Precautions such as using local chemical antiseptics are important ${ }^{(14)}$, as well as the caregiver washing their hands before handling the area and smelling the area to verify odor change $\mathrm{e}^{(15)}$.

Umbilical hernias are frequent in infants. Usually it is absent at birth, only appearing between the first and second months of life. It usually increases in size before spontaneously disappearing around the 4 th month ${ }^{(14)}$. The use of belts, bands, coins and buttons are not recommended as they do not modify the natural evolution of a hernia ${ }^{(13)}$. However, culturally these practices are still common, as observed in this study, prior to the group health education activity. Health professionals should work with mothers and baby caregivers in order to avoid such practices that may put the life of the newborn at risk, as in the case of infection caused by the placement of coins in the newborn's umbilical stump. Thus, health professionals can establish a link with these caregivers and promote an open dialogue in which the health care provider is not the beholder of absolute knowledge, but can instead demonstrate what traditions can be changed by caregivers in relation to newborn care through scientific knowledge.

In the development of care, family members are faced with newborn colic/cramps which are characterized by repeated episodes of crying and irritation in sufficient intensity to cause difficulties in a normal child and family apprehension. The diagnosis should only be made when other causes for the crying are eliminated, including gastroesophageal reflux with esophagitis and food allergy ${ }^{(14)}$.

There is a lack of colic etiology, and the treatment is empirical. If the child is being breastfed, removing dairy from the mother's diet, and taking extra care with the mother's calcium intake are options. Alternatively, along with removing cows' milk and dairy products, removing eggs, wheat and nuts 
from the mother`s diet one at a time. When the child is receiving cow's milk, replace it with soy milk ${ }^{(14)}$. Other measures that may help calm the pain are massaging the baby's belly clockwise, moving their legs toward the body, applying dry and warm compresses, tucking the baby in the mother's lap and touching the baby's belly to the mother's belly ${ }^{(12)}$.

On caring for sunbathing, the newborn receives his mother's vitamin D in breast milk, which is inactive in the newborn's body. For this vitamin to synthesize and provide the absorption of calcium, the baby needs to sunbathe. Rays transform inactive vitamin D into active, allowing for better absorption of calcium, essential for the development and growth of bones. Therefore, sunbathing should be daily, or at least three times a week and started at 30 days of the baby's life. The sun's rays between ten in the morning and four in the afternoon are very strong and harmful to the baby ${ }^{(13)}$. In the present study, this knowledge was extensive. However, we observed decontextualized knowledge, in which people reported that the sun prevents pneumonia.

With regard to skin color, it is known that yellowish skin occurs from excess bilirubin in the blood, a yellowish pigment, normally produced by the metabolism of red blood cells. Excess arises from difficulty of the liver to capture the entire amount of bilirubin produced, thereby accumulating in the blood. Most often it spontaneously regresses around the tenth day of the baby's life, but it is important to sunbathe the baby in the morning or in the afternoon because the light helps in eliminating bilirubin ${ }^{(13)}$. In the study, some people reported that the yellow color is a normal occurrence in the newborn, even after the group's guidance.

On the care of breastfeeding, it appears that the permanence of exclusive breastfeeding until six months of life ${ }^{(16)}$ can be achieved through organized and planned educational interventions. The formation and strengthening of the bond between parents and baby is also important in assisting parents in perceiving the baby's needs and encouraging them to provide the necessary care for it. There are several meanings of a crying baby, such as hunger, pain or it being uncomfortable. In this study, and also before and after the group intervention, the reasons for the presence of crying refer to the presence of hunger and not due to poor breast milk. It is known that introducing liquids and teas, often a trans-generational habit, creates a risk of breast engorgement due to the decline in milk consumption of the newborn, which damages the nipples and causes pain. Pain in the act of breastfeeding is one of the causes of early weaning. Guidance and support to women in pre-breastfeeding and post-partum must be constant.

Moreover, these problems can be avoided when correcting the latching position of the child to the mother's breast and when the nurse explains to the mother the real importance of breast milk for the baby. The correct technique should provide the following: the front of the child's face to the breast with nose at the height of the nipple, the baby's body close to the mother, baby with its head and body aligned and well supported, the mouth should be wide open, suckling up most of the areola, lower lip turned out, chin touching the breast and nostrils free ${ }^{(1)}$.

Regarding the care of the child's health record book, it must be completed and evaluated at each visit with their health care professional. The mother and/or other caregivers should be aware of dates for immunization, which occur in almost every month of a baby's life until it is one year old. In this study, it is clear that before the group intervention, only $78.6 \%$ of respondents assessed the children's health book every month, which can lead to forgetting or missing the deadlines for vaccines.

Regarding the care of physiological elimination, constipation is rare in breastfed children. Some babies do not evacuate every day and may stay up to a week without a bowel movement. If, despite this time, the stools are pasty and the child is suckling well, it is not a problem. If the baby is being breastfed and only has a few days without a bowel movement, the healthcare provider should advise the mother/caregiver that 
they should not give the baby fruit, laxatives or teas. It is important to inform the caregiver that in this period, it is not an illness or disease ${ }^{(13)}$.

In the case of disposal of a white vaginal discharge and/or blood, which begins on the second or third day and continues until the seventh day due to the presence of female hormones circulating in the baby ${ }^{(14)}$, the study showed that this is one of the major questions about the care of the newborn female.

Regarding the danger signs of a newborn, the literature indicates signs of serious health problems that can cause death of newborns, so in order to avoid this, the mother and the family need to recognize the danger signs ${ }^{(14)}$ such as vomiting and fever, the caregiver should seek health assistance for evaluating the newborn.

Children under two months can fall ill and die in a short time from serious bacterial infections. There are signs that indicate the need for referral to a reference service urgently, such as respiratory problems; difficulty or inability to eat; cold body; fever; red, swollen eyelids or secretion; skin redness, swelling, pus or foul odor around the cord or umbilicus; seizures/blackouts; jaundice ${ }^{(14)}$.

\section{Conclusions}

The study identified the existence of unknown knowledge of newborn care during the development of educational actions for families of newborns, causing difficulties for the adoption of healthy habits. Improper practices, even if reduced, lead to error in the care of newborns, enabling risk for some kind of accident. Some inadequacies were due to care from popular knowledge. Therefore, it is urgent to encourage implementation of public policies for the education of the population.

We also conclude that the type of study employed (testing of knowledge before and after) allowed for identifying and promoting and health prevention and promotion actions directed at newborn care in one or more actions.
Study limitations are visible in the number of educational interventions, the number of participants and knowledge acquired in the care of other children.

\section{Collaborations}

Gomes ALM and Rocha CR contributed to the design, collection of field data analysis, data interpretation and writing of the article. Henrique DM, Santos MA and Silva LR contributed to the design and final approval of the version to be published.

\section{References}

1. Ministério da Saúde (BR). Secretaria de Atenção à Saúde. Departamento de Ações Programáticas e Estratégicas. Atenção à saúde do recém-nascido: guia para os profissionais de saúde. [Internet] 2011 [citado 2014 nov 11]: [cerca de 190 p]. Disponível em: http://www.fiocruz.br/redeblh/ media/arn_v1.pdf

2. Cervera DPP, Parreira BDM, Goulart BF. Educação em saúde: percepção dos enfermeiros da atenção básica em Uberaba (MG). Ciênc Saúde Coletiva. 2011; 16(Supl. 1):1547-54.

3. Roecker S, Marcon SS. Educação em saúde na estratégia da saúde da família: o significado e a práxis dos enfermeiros. Esc Anna Nery. 2011; 15(4):701-9.

4. Oliveira MB, Cavalcante EGR, Oliveira DR, Leite CEA, Machado MFAS. Health education as practice of nurses in family health strategy. Rev Rene. 2013; 14(5):894-903.

5. Figueiredo MFS, Rodrigues-Neto JF, Leite MTS. Modelos aplicados às atividades de educação em saúde. Rev Bras Enferm 2010; 63(1):117-21.

6. Fonseca LMM, Del'Angelo N, Castro FSF, Scochi CGS. Aprendizagem participativa de mães e familiares sobre a saúde do recém-nascido: relato de experiência. Rev Cult Ext USP. 2011; 6(2):91-7.

7. Vieira I. IBGE: com taxa de fecundidade baixa, Brasil tende a ser tornar país de idosos. [Internet] 2012 [citado 2013 jul 12]. Disponível em: http:// agenciabrasil.ebc.com.br/noticia/2012-10-17/ ibge-com-taxa-de-fecundidade-baixa-brasiltende-ser-tornar-pais-de-idosos 
8. Manfroi EC, Macarini SM, Vieira, ML. Comportamento parental e o papel do pai no desenvolvimento infantil. Rev Bras Cresc Desenvolv Hum [periódico na Internet] 2011 [citado 2014 jun 8]; 21(1):[cerca de 10 p]. Disponível em: http:// pepsic.bvsalud.org/pdf/rbcdh/v21n1/07.pdf

9. Instituto Brasileiro de Geografia e Estatística (IBGE). Nascidos vivos, ocorridos no ano, por sexo e local do nascimento, segundo a idade da mãe na ocasião do parto. [Internet]. 2011 [citado 2014 jul 2]. Disponível em: ftp://ftp.ibge.gov.br/Registro_ Civil/2011/pdf/tab_1_3.pdf.

10. Teixeira SVB, Rocha CR, Moraes DSD, Marques DM, Villar ASE. Educação em saúde: a influência do perfil sócio-econômico-cultural das gestantes. Rev Enferm UFPE online [periódico na Internet] 2010 [citado 2014 jul 11]; 4(1): [cerca de 9 p]. Disponível em: http://www.revista.ufpe.br/ revistaenfermagem/index.php/revista/article/ viewFile/546/pdf_303

11. Fernandes JD, Machado MCR, Oliveira ZNP. Prevenção e cuidados com a pele da criança e do recém-nascido. An Bras Dermatol. 2011; 86(1):102-10.
12. Ministério da Saúde (BR). Secretaria de Atenção à Saúde. Departamento de Atenção Básica. Saúde da criança: crescimento e desenvolvimento. Brasília: Ministério da Saúde; 2012.

13. Ministério da Saúde (BR). Secretaria de Atenção à Saúde. Departamento de Atenção Básica. Guia prático do agente comunitário de saúde. Brasília: Ministério da Saúde; 2009.

14. Wanderley LD, Barbosa GOL, Pagliuca LMF, Oliveira PMP, Almeida PC, Rebouças CBA. Verbal and non-verbal communication of blind mother during child's body hygiene. Rev Rene. 2010; 11(n esp):150-9.

15. Pati S, Chauhan AS, Panda M, Swain S, Hussain MA. Neonatal care practices in a tribal community of Odisha, India: a cultural perspective. J Trop Pediatr. 2014; 60(3):238-44.

16. Linhares EF, Silva LWS, Rodrigues VP, Araújo RT. Influência intergeracional no cuidado do coto umbilical do recém-nascido. Texto Contexto Enferm. 2012; 21(4):828-36. 